them facilities for study, travel and recreation. Lecture courses for such students and other overseas visitors, an information services department, exhibitions and a series of informative pamphlets are among the ways in which the Council has sought to help overseas visitors to understand the British way of life.

Turning to the functional activities, the greater part of the book grant has been concentrated on building up British Council libraries, especially in liberated Europe. The book review scheme was extended to cover many new countries, and circula. tion of British Books to Come was doubled, the periodical now reaching sixty-three countries. Fortyone brochures in twelve languages were published. Although the Book Export Scheme introduced in 1941 largely as a war-time measure has been withdrawn, the Council's book copyright work has largely increased. The Council was also instrumental in allocating and distributing to numerous learned institutions back sets of periodicals given by individuals, learned societies and publishers, and as a further step towards overcoming the shortage of back sets of periodicals and filling the gap in information caused by the War, it has arranged for the indexes and contents list of sixty specialist journals for the years 1939-45 to be microfilmed. One set of these microfilms will be lodged in each of fourteen European countries and in China, either in the principal library where a microfilm reader is available, or in the Council's library. Much information about publications now available in Europe has been obtained for British organisations, and 533 new exchanges between British and foreign periodicals, involving thirty-nine different countries, were arranged during the year.

The total distribution of Monthly Science News was about 70,000 at the end of March, and the distribution of articles on engineering and technology was continued, 113 sets going to thirty-nine countries. The Information Section was fully occupied, chiefly with bibliographical inquiries, and requests from Moscow for books, papers, and other scientific information considerably increased. An exhibition of British medical books published during the War was held in Moscow, and articles sent to Moscow for publication included a series on the work of the Department of Industrial and Scientific Research. Scientific supplies to China considerably increased during the year, and the report refers to the lasting impression on the Chinese people made by the Council's staff during the last three and a half years under Dr. Needham's direction.

The British Medical Bulletin has now reached its fourth volume, and sets of volumes 2 and 3 were sent to liberated Europe as soon as possible. A selection of articles from the Bulletin made by members of the Medical Faculty of Leyden was published in January 1946 as a book under the title "Recent Medical Science, 1940-5". About five hundred foreign and Empire medical journals are now received in exchange for the Bulletin, in addition to others received for the Medical Library, while fifty medical films were reviewed for distribution overseas.

The engineering consultant, Prof. S. J. Davies, visited Greece in the autumn of 1945 to investigate questions affecting engineering and scientific education, particularly the arrangement of courses, the equipment and libraries available, and the distribution of British technical books and periodicals. In con- junction with the librarian of the Science Department, the Agricultural Department prepared a handlist of British Biological Societies and Journals, and a corresponding list covering agricultural societies and journals is in preparation. An agricultural officer was appointed to the Council's staff in Turkey, and original articles were supplied for the British Agricultural Bulletin published in Turkey.

In addition to the scholarship programme already mentioned, the educational services of the Council include the recommendation, at the request of universities, schools and other educational institutions overseas, of suitable British candidates for vacant teaching posts in English language and literature, in British history and institutions and on other subjects. A list of such appointments made or recommended during the year is given in the report, as well as a note on three specialized vacation courses provided in the summer of 1945: a two weeks special electrical engineering course at Queen Mary College, London; a residential course on "Britain, its System of Government, of Education and of Life, and its Ideals of Empire" at the University of St. Andrews; and a residential course, at Wadham College, Oxford, in conjunction with the Oxford University Delegacy for Extra.Mural Studies.

\section{8\% \\ IRON AGE DISCOVERIES IN CZECHOSLOVAKIA}

TN the Illustrated Lon 1 November 3, Prof f $1 /$ Absalon, of Brno, describes the remarkable dis 4 eries made by his grandfather, Dr. Waykf1; '1'the cave of Byči Skala. Wankel's exavat of 1872 have only been described in a Aflar tourist guide, "Bilder aus der mährischen Sfnteiz", published in 1882, but have now been supplemented by Prof. Absalon's own operations between 1922 and 1939 .

The cave was inhabited in the Upper Palæolithic age and has left stratified relics of a "primitive Aurignacian', a Gravettian and a long Magdalenian occupation. A completely sterile travertine seals the palæolithic layers and represents a hiatus, corresponding to the Mesolithic, but the cave was reoccupied in Neolithic times and thereafter down to the first Iron Age.

The most significant discoveries of Wankel referred to the last-named occupation. The cave had been used as the workshop of a smith, who doubtless used the rich iron ores of the district. Wankel recovered and described an important series of smiths' tools, including tongs, the earliest dated examples from temperate Europe, but these unfortunately have never yet been illustrated. Absalon figures another discovery that may be of even greater significance, namely, a ring of cast iron. If metallurgical study proves that it was really cast-and Prof. Absalon offers it to his English colleagues for examinationit will be the oldest piece of cast iron from Europe ; but without microscopic examination it is actually very difficult to distinguish cast from forged iron.

The smithy was abandoned when use was made of the cave for the burial of an Early Iron Age chieftain, with rites more Oriental than European. Like the occupants of the 'Royal Tombs' of Ur, this Hallstatt chief was conveyed to the tomb on a wheeled wagon 
which was buried with him, and was accompanied by numerous retainers slaughtered at his obsequies. More than forty human skeletons were found, all but five being those of young women. Numerous animals and enormous quantities of grain were also deposited with the dead, as well as a fine variety of ornaments and implements in bronze and iron, characteristic of the late Hallstatt Age. The body was, however, burned and the site of the pyre covered with a layer of large stones.

The illustrations of the Hallstatt objects in Wankel's book reproduced here are inadequate, and a full publication of the relics is to be desired. Prof. Absalon, however, states that a monograph on the Palæolithic excavations has just been published.

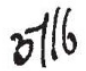

\section{FORTHCOMING EVENTS}

(Meetings marked with an asterisk * are open to the public)

Tuesday, December 31

RoYal INSTutution (at 21 Albemarle Street, London, W.1), at 3 p.m.-Poof H/ Hartridge, F.R.S.: "Colours and How we See Then' (enris ons Juvenile Lectures, 2).*

Wednesday, Jạnuary 1

ROYL SWCIETY of ARTS (at John Adam Street, Adelphi, London, W.C.2), at 2.30 p.m--Mr. Derek McCulloch: "The Children's Hour" (Dr. Mann Juvenile Lecture). BRITISH INSTITUTE OF RADIOLOGY (in the Reid-Knox Hall, 32 Wel-
beck Street, London, W.1) at 5 p.m.-.Prof. W. V. Mayneord: "The Applications of A tomic Physics in Medicine" (succeeding lectures on January 8, 15, 22, 29 and February 5).

Thursday, January 2

ROYAI INSTITUTION (at 21 Albemarle Street, London, W.1), at 3 p.m.- Prof. H. Hartridge, F.R.S.: " "Colours and How we See

Royal Society of Medicine, NeURology Section (at 1 Wimpole Street, London W.1), at 8 p.m.-Prof. E. D. Adrian, F. S. "General Principles Governing Nervous Activity" (Hughlings Jackson Memorial Lecture).

Friday, January 3

Institution of Mechanical Enginems (at Storey's Gate, St. James's Park, London, S.W.1), at 5.30 p.m. Mr. H. G. Conway, Mr. S. M. Parker and Mr. D. A. L. Robson: "The Development of Aircraft Hydraulic Machinery" (Discussion).

Saturday, January 4

Roxal Instrirution (at 21 Albemarle Street, London, W.1), at 3 p.m.- Prof. H. Hartridge, F.R.S.: "Colours and How we See $\sqrt{ }$

\section{APPOINTMENTS VACANT}

APPLIOATIONS/are invited for the following appointments on or before the date mentioned :

EpPOYIONA Psychologist for the City of Portsmouth-The Chi f Fafign Officer, Education Offices, 1 Western Parade, Southsea (rantaiy ).

Py SpIPAL (OFICER (temporary) to take charge of development of electrical and mechanical earth-moving and road-making plant required by the Army, and SENIOR OFFICERS (temporary) with high qualiffcations in Civil, Structural or Mechanical Engineering, at the Military Engineering Experimental Establishment, Christchurch, Hants. The Director of Scientific and Technical Administration (D), quoting No. D. 2246 (January 6).

CLINICAL BACTERIOLOGIS'T-The House Governor, Royal Victoria Inflrmary, Newcastle-upon-Tyne (January 18).

SENIOR LECTURER IN PHYSICS-The Principal, Sir John Cass Technical Institute, Jewry Street, London, E.C.3.

LECTURER IN ZOOLOGY, and a LECTURER IN MATHEMATICS-The Registrar, University of Tasmania, Hobart, Tasmania.

$\checkmark$

REPOR TS and other PUBLICATIONS

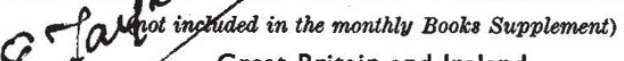

Great Britain and Ireland

Qritish Wolding Research Association. Arc Welded Structural Steelwork, 1: Stanchion Bases, Caps and Joints. Recommendations for the Design, Fabrication and Erection of Welded Stanchion Details. Pp. 12. (London: British Welding Research Association, 1946.)
Proceedings of the Royal Irish Academy. Vol. 51, Section A, No. 2: The Calibration of a Photo-electric Nucleus Counter. By P. J. Nolan and L. W. Pollak. Pp. 7-32. (Dublin: Hodges, Figgis and Co.,
Ltd.; London: Williams and Norgate, Ltd., 1946.) $2 s$.
[187 Imperial Forestry Institute: University of Oxford. Twentyflrst Annual Report, 1944-45. Pp. 16. (Oxford: Imperial Forestry
[237 Edinburgh and East of Scotland College of Agriculture. Calendar for 1946-1947. Pp. 50. (Edinburgh : Edinburgh and East of Scotland College of Agriculture, 1946.)
[237 Radio Transmission of Finger Prints. By Supt. F. R. Cherrill. Pp. 12. (London: Commissioner of Police of the Metropolis, 1946.) [237 Privy Council Office: Treasury. Report of the Committee on the Provision for Social and Economic Research. (Cmd. 6868.) Pp. 16. (London: H.M. Stationery Office, 1946.) 3d. net. Humane Destruction of Rats and Mice. By Major C. W. Hume.
(London: Universities Federation for Animal Welfare, Pp.6.) (Lond
[237 Report of the Astronomer Royal to the Board of Visitors of the Royal Observatory, Greenwich, read at the Annual Visitation of the Royal Observatory, June 1, 1946. Pp. 26. (London: Royal
[247 Royal Society. Report on the Needs of Research in Fundamental Science After the War. Pp. 62. (London: Royal Society, 1945.) [257 Current Affairs. (Published fortnightly.) No. 8: Food and Farming. By the Rt. Hon. Walter Eliot. Pp. 20. (London: Bureau of Current Affairs, 1946.) 88. 6d. per annum. Map Review. (Published fortnightly.) No. 6: From June 13th to June $26 \mathrm{th}, 1946.40 \mathrm{in.} \times 30$ in. (London: Bureau of Current Affairs, 1946.) 18s. 6d. per annum. Farm Mechanization Enquiry. Farm Case Study No. 1: A Study
of a 200 Acre South Warwickshire Clay Farm in relation to its Use of Machinery. By John W. Y. Higgs, from the field work of Miss H. J. Thompson. (Published for the National Institute of Agricultural Engineering.) Pp. 20. (London: H.M. Stationery Office, 1946.) 18. net.
Verticillium on Mushrooms : Consideration of the Commercial Aspect of the Disease, with Notes on its Introduction, Prevention and Control. By Fred C. Atkins. Pp. 56. (Yaxley, Peterborough : Midlands Group Publications, 1946.) 58 .
Burton-on-Trent Natural History and Archæological Society. Loca] Burton-on-Trent Natural History and Archæological Society. Loca! Records for 1945. Edited by H. J. Wain. Pp. 24. (Burton-on-Trent H. J. Wain, Hon. Sec., Dunelm, Bretby Lane, 1946.) 18 . Pp. 12. (Oxford: Dr. John R. Baker, Sec., University Museum, 1946.) [18 Institution of Civil Engineers and the Institution of Municipa] an County Engineers. Report of Joint Committee on Location of Underground Services. Pp. 12. (London: Institution of Civil Engineers, 1946.) 6d. [18 Department of Scientiflc and Industrial Research : Fuel Research. Tignite and Peat. By Dr. C. M. Cawley and Dr. J. G. King. Pp. iv +29 . (London: H.M. Stationery Office, 1946.) 6d. net. Ministry of Health: Department of Health for Scotland. Report of the Inter-Departmental Committee on the Rag Flock Acts. (Cmd. 6866.) Pp. iv + 36. (London: H.M. Stationery Office, 1946.) $9 d$. net.
Royal College of Physicians of Edinburgh. Annual Report by the Royal College of Physicians of Edinburgh. Annual Report by the Royal College of Physicians of Edinburgh, 1946.) Fitzwilliam Museum, Cambridge. Annual Report for the Year Thirty-seventh Annual Report for the Year 1945. Pp. 4. (Cambridge: Thirty-seventh Annual Report for the Year 1945. Pp. 4. (Cambridge
Fitzwilliam Museum, 1946.) Registrar-General's Statistical Review of England and Wales for Registrar-General's Statistical Review of England and Wales for
the Year 1941. (New Annual Series, No. 21.) Tables, Part 2: Civil. the Year 1941. (New Annual Series, No. 21.) Tables, Part 2 : Civil.
Pp. vi +92. (London: H.M. Stationery Office, 1946.) 18. 6d. net. [18 Pp. vi +92 . (London: H.M. Stationery Office, 1946.) 18. $6 d$. net. I18 reference to the Frosts of May 1935. Second edition. Pp. $111+12$ plates. (London: H.M. Stationery Office, 1946.) $28.6 \dot{d}$. net. [18 Fngineering Research in the University : the Inaugural Lecture to the Chair of Civil and Mechanical Engineering given in the University of London, Queen Mary College. By Prof. Edmund Giffen. Pp. 12. (London: Oxford University Press, 1946.) 18.6d. net. 24 (N.S.), Scientifle Proceedings of the Royal Dublin Society. Vol. 24 (N.S.), No. 10: Observations on the Pasmo Disease of Flax and on the Causal Fungus Sphaerella linorum Wollenweber. By J, B. Loughnane, R. McKay and H. A. Lafferty. Pp. 89-98+plates 2-4. 38 . Vol. 24
(N.S.), No. 11: A Study of Septoria oxyspora Penz. and Sacc. Isolated from Diseased Barley. By Dr. Robert McKay. Pp. 99-110+plates 5-7. 38. Vol. 24 (N.S.), No. 12: Studies on Ureides, Part 2, The Chemistry of Triuret and related Compounds. By A. E. A. Werner and J. Gray. Pp. 111-118. 1s. Vol. 24 (N.S.), No. 13: Evidence for a Mitotic Hormone; Observations on the Mitoses of the Embryo-Sac of Fritillaria imperiatis. By Prof. Henry H. Dixon. Pp. 119-124 plates $8-10$. 2s. $6 d$. Vol. 24 (N.S.), No. 14 : The Occurrence of Nicke and Magnetite in some Irish Serpentines, in conjunction with a Magnetic Survey. By D. W. Bishop. Pp. 125-134. 1s. (Dublin : Hodges, Figgis and Co., Ltd.; London: Williams and Norgate, Ltd. 1946.)

Economic Proceedings of the Royal Dublin Society. Vol. 3, No. 18 : The Influence of Mechanical Treatment of Milk and Cream on the Size Distribution of the Fat Globules. By J. Lyons. Pp. 249-272. (Dublin : Hodges, Figgis and Co., Ltd. ; London: Williams and Norgate, Ltd., 1946.) 28. Bulletin No, 17. The Cultivation of the Cricket Bat Willow. Pp. $50+17$ plates. (London: H.M. Stationery Office, 1946.) 28. net.

Department of Scientific and Industrial Research : Forest Products Research Laboratory. Leaflet No. 39: Timber Decay and its Control. Pp. 12. (Princes Risborough : Forest Products Research Laboratory, 1946 .)

Ministry of Health. Nurses Salaries Committee: Mental Nurses Sub-Committee. Further Recommendations: Mental Nurses S.C. Notes No. 7. Pp. 12. (London: H.M. Stationery Office, 1946.) 